\title{
Memory-impairing effects of local anesthetics in an elevated plus-maze test in mice
}

S.L. Blatt and R.N. Takahashi
Departamento de Farmacologia, Centro de Ciências Biológicas, Universidade Federal de Santa Catarina, Florianópolis, SC, Brasil

\section{Correspondence \\ R.N. Takahashi \\ Rua Ferreira Lima, 82 \\ 88015-420 Florianópolis, SC \\ Brasil \\ Fax: 55 (048) 222-4164 \\ Research supported in part by CNPq \\ S.L. Blatt is the recipient of a \\ CNPq fellowship.}

Received April 2, 1997

Accepted January 14, 1998

\section{Abstract}

Post-training intracerebroventricular administration of procaine (20 $\mu \mathrm{g} / \mu \mathrm{l})$ and dimethocaine $(10 \mathrm{or} 20 \mu \mathrm{g} / \mu \mathrm{l})$, local anesthetics of the ester class, prolonged the latency $(\mathrm{s})$ in the retention test of male and female 3 -month-old Swiss albino mice (25-35 g body weight; $\mathrm{N}=140$ ) in the elevated plus-maze (mean \pm SEM for 10 male mice: control $=41.2 \pm$ $8.1 ;$ procaine $=78.5 \pm 10.3 ; 10 \mu \mathrm{g} / \mu \mathrm{l}$ dimethocaine $=58.7 \pm 12.3 ; 20$ $\mu \mathrm{g} / \mu \mathrm{l}$ dimethocaine $=109.6 \pm 5.73$; for 10 female mice control $=34.8$ $\pm 5.8 ;$ procaine $=55.3 \pm 13.4 ; 10 \mu \mathrm{g} / \mu \mathrm{l}$ dimethocaine $=59.9 \pm 12.3$ and $20 \mu \mathrm{g} / \mu \mathrm{l}$ dimethocaine $=61.3 \pm 11.1)$. However, lidocaine $(10$ or $20 \mu \mathrm{g} / \mu \mathrm{l})$, an amide class type of local anesthetic, failed to influence this parameter. Local anesthetics at the dose range used did not affect the motor coordination of mice exposed to the rota-rod test. These results suggest that procaine and dimethocaine impair some memory process(es) in the plus-maze test. These findings are interpreted in terms of non-anesthetic mechanisms of action of these drugs on memory impairment and also confirm the validity of the elevated plusmaze for the evaluation of drugs affecting learning and memory in mice.

\section{Introduction}

Several investigators have shown that learning and memory can be modified by drugs which affect the central dopamine (DA) neuronal system (1-5). Thus, in an active or passive avoidance task, activation of postsynaptic DA receptors has been reported to induce an impairment of memory $(2,3,5)$. Moreover, it is known that the mesolimbic DA system is involved in the processes underlying memory consolidation (6) and there is a growing body of evidence that some chemically related local anesthetics, besides cocaine, have an appreciable DA agonist activ- ity. For example, the ester class local anesthetics procaine and dimethocaine have been reported to be self-administered by laboratory animals $(7,8)$. Among them, dimethocaine was shown to be the local anesthetic with greatest affinity for the DA uptake binding site (9) and to produce other behavioral effects consistent with DA agonist activity, such as rotational behavior in rats with lesions of the substantia nigra (10), reinforcing anxiogenic effects in mice (11) and other cocaine-like discriminative responses $(12,13)$. Procaine is probably the most extensively studied local anesthetic after cocaine and has been shown to display compara- 
tively low affinity for the DA transporter. Its reinforcing effects seem to be less potent than those of dimethocaine (8).

Recent studies have suggested that the elevated plus-maze test may be useful for evaluating learning and memory in mice (1417). In light of these considerations, the present study was designed to compare the ability of local anesthetics of both the ester and amide class, procaine, dimethocaine and lidocaine, to affect elevated plus-maze learning in male and female mice. In addition, we examined the possible interference of these drugs with motor coordination.

\section{Material and Methods}

\section{Animals}

Male and female Swiss albino mice weighing 25-35 g, from our own colony, were kept in cages in groups of 15-20 with free access to food and water and maintained in a room with controlled temperature (23 \pm $1^{\circ} \mathrm{C}$ ) and on a 12:12-h light-dark cycle (lights on 7:00 a.m.). Female mice were tested without monitoring the estrous cycle.

\section{Drugs}

Procaine $\mathrm{HCl}$, lidocaine $\mathrm{HCl}$ (Sigma Chemical Co., St. Louis, MO) and dimethocaine $\mathrm{HCl}$ (Hoffman-La Roche, Nutley, NJ) were dissolved in saline and injected intracerebroventricularly (icv). All drugs were administered at doses of 10 or $20 \mu \mathrm{g} / \mu \mathrm{l}$. A Hamilton microsyringe and injection needle were used for icv injections by the "free hand" technique according to the procedure described by Laursen and Belknap (18). The drugs were injected in a volume of $5 \mu \mathrm{l} /$ mouse over 1 min under brief ether anesthesia. The bregma fissure was the reference for the injection needle. The control group received a similar volume of saline injection under the same conditions. After the experiment, the site of injection was checked by histological examination. Animals presenting any signs of needle misplacement or hemorrhage were discarded. Neither insertion of the needle nor injection of $5 \mu \mathrm{l}$ saline had a significant influence on gross behavioral responses.

\section{Elevated plus-maze test}

The plus-maze was made of plywood and consisted of two open arms $(21.5 \times 7.5 \mathrm{~cm})$ and two enclosed arms $(21.5 \times 7.5 \times 20 \mathrm{~cm})$ which extended from a central $7.5 \times 7.5 \mathrm{~cm}$ platform. The plus-maze was elevated $38 \mathrm{~cm}$ above the floor. The enclosed arms were painted black.

The procedure of the test was similar to that described by Itoh et al. (14). On the $1 \mathrm{st}$ day (training) a mouse was placed at the end of one open arm, facing away from the central platform. The latency for the mouse to move from the open to one of the enclosed arms was recorded. Following entry into the arm the animals were allowed to explore the apparatus for $30 \mathrm{~s}$. Twenty-four hours later, the second trial (retention test) was performed. The drugs were administered immediately after the 1st training day, i.e., soon after the mouse was removed from the maze.

For the plus-maze task, 140 mice were divided into two sets (males and females) each consisting of seven groups of 10 mice.

\section{Rota-rod test}

Additional groups of mice were divided into seven experimental groups of 7-10 animals of each sex and tested on the rota-rod.

The rota-rod apparatus consisted of a rotating bar $(2.5 \mathrm{~cm}$ in diameter) covered with sandpaper and revolving at $7 \mathrm{rpm}$. Mice were placed upon the bar and the time spent upon the rotating bar was recorded up to 120 s (day 1). Immediately after the session on day 1 , mice were injected $i c v$ with procaine, dimethocaine and lidocaine. Twenty-four hours later the performance on the rota-rod 
was again assessed for all animals.

\section{Statistical analysis}

The results are reported as means \pm SEM and were analyzed by two-way analysis of variance (ANOVA). When ANOVA was significant, the Newman-Keuls test was used to compare each treatment with the control group. Further comparisons betwen day 1 and 2 were carried out by the paired Student $t$-test. The criterion for statistical significance was $\mathrm{P} \leq 0.05$ for all evaluations.

\section{Results}

The effects of $i c v$ injection of procaine, dimethocaine and lidocaine on latency of female mice to move from the open arm of the maze are shown in Figure 1A. Control animals showed a significantly shortened latency on day 2 compared to the training session. Mice injected with procaine $(20 \mu \mathrm{g} /$ $\mu \mathrm{l})$ and dimethocaine $(10$ or $20 \mu \mathrm{g} / \mu \mathrm{l})$ immediately following the training session showed a prolonged latency in the plus-maze retention test (day 2).

A quite similar effect of these drugs on performance of mice in the retention test was also found in male mice (Figure 1B). Thus, procaine and dimethocaine prolonged the latency of mice to move from the open arm to the enclosed arm of the plus-maze on day 2. Although no statistical difference in terms of gender was detected by two-way ANOVA, the prolongation of latency of male mice was statistically significant compared to control animals (Figure 1B). Again, lidocaine (10 or $20 \mu \mathrm{g} / \mu \mathrm{l})$ did not affect the shortened latency on the 2nd day, thus showing the same pattern presented by control animals (Figure 1B).

In order to examine the eventual interference of motor impairing effects of these treatments with plus-maze performance, additional groups of mice were tested on the rota-rod apparatus. Local anesthetics at the dose range used in the present study did not affect the motor coordination of mice exposed to the rota-rod test (Table 1).

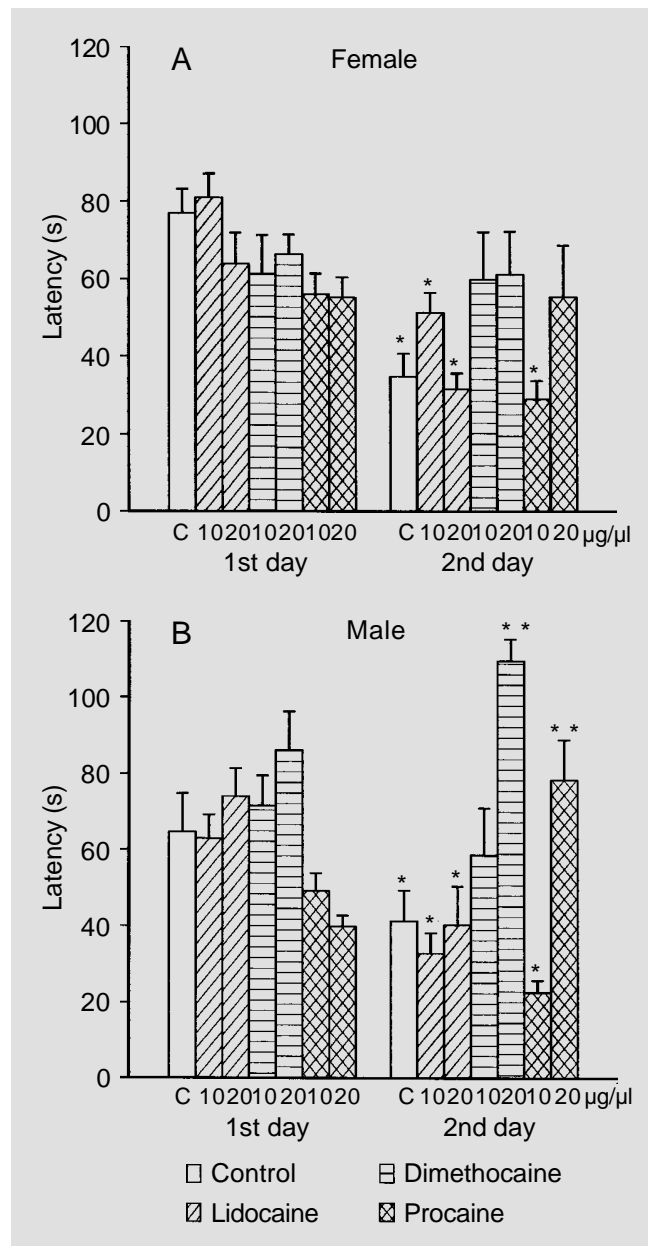

Figure 1 - Effects of intracerebroventricular administration of lidocaine, dimethocaine and procaine on the latency of female $(A)$ and male $(B)$ mice to move from the open arm to the enclosed arm of the plus-maze. Data are reported as means \pm SEM of 10 mice. * $P \leq 0.05 \mathrm{com}$ pared to the 1 st day (Student $t$ test). ${ }^{* *} \mathrm{P} \leq 0.05$ compared to the control group (Newman-Keuls test).
Table 1 - Influence of local anesthetics injected icv immediately after the session on day 1 on the ability of male mice to remain on the rota-rod.

Day 2, performance measured $24 \mathrm{~h}$ after the training session. There were no statistical differences amongst anesthetics or days.

\begin{tabular}{lccc}
\hline Treatment & Dose $(\mu \mathrm{g} / \mu \mathrm{l})$ & \multicolumn{2}{c}{ Time $(\mathrm{s})$ on the rota-rod } \\
\cline { 3 - 4 } & & Day 1 & Day 2 \\
\hline Saline $(\mathrm{N}=10)$ & 0 & $118.7 \pm 1.2$ & $120.0 \pm 0.0$ \\
Lidocaine $(\mathrm{N}=7)$ & 10 & $120.0 \pm 0.0$ & $120.0 \pm 0.0$ \\
Lidocaine $(\mathrm{N}=7)$ & 20 & $115.6 \pm 4.0$ & $119.0 \pm 0.3$ \\
Procaine $(\mathrm{N}=9)$ & 10 & $119.1 \pm 0.6$ & $120.0 \pm 0.0$ \\
Procaine $(\mathrm{N}=8)$ & 20 & $119.6 \pm 0.2$ & $120.0 \pm 0.0$ \\
Dimethocaine $(\mathrm{N}=8)$ & 10 & $119.0 \pm 0.6$ & $120.0 \pm 0.0$ \\
Dimethocaine $(\mathrm{N}=9)$ & 20 & $118.2 \pm 0.8$ & $115.0 \pm 1.5$
\end{tabular}




\section{Discussion}

The local anesthetics of the ester class procaine and dimethocaine injected $i c v$ into mice of both sexes prolonged the latency to move from the open to the one enclosed arm of the elevated plus-maze. However, the same doses of lidocaine, an amide class anesthetic, did not alter this response. Itoh et al. (14) and other investigators (15-17) have suggested that the changes in the latency of mice and rats to go from an open arm to an enclosed arm of the elevated plus-maze are an indicator of learning and memory. However, it should be kept in mind that such an experimental situation involves an aversive experience of height and openness of the maze that may induce escape learning responses in the animals. Indeed, in a recent serie of studies, Graeff et al. (19-21) reported an interesting procedure using the socalled T-maze in which the same rat is tested for escape latency (time to escape from open arm) and for inhibitory avoidance latency (time to withdrawal from the enclosed arm). Thus, these investigators suggested that the elevated T-maze is a potentially useful model for the simultaneous study of anxiety and memory.

In the present study it is clear that mice were tested only for one task, the one-way escape from the open arm, a response which may be considered to measure the unconditioned fear of the animals. Therefore, we could not separate the influence of fear/ anxiety levels on the evaluation of memory in the elevated plus-maze. Nevertheless, taking into account the finding of Miyazaki et al. (17) that anxiolytic and anxiogenic drugs do not affect learning or memory as measured by the elevated plus-maze test in mice, and considering that in our study the retention test was carried out $24 \mathrm{~h}$ after drug treatment and that the changes in latency were achieved without overt motor incoordination of mice, it seems reasonable to suggest that procaine and dimethocaine impaired some memory process(es) involved in the plus-maze task.

Although the exact mechanism by which procaine and dimethocaine exert their memory-impairing effects has yet to be identified, it is tempting to speculate about a role for dopaminergic rather than local anesthetic mechanisms in these responses. As mentioned before, both drugs display various behavioral effects consistent with DA agonist activity $(8,10,11,13)$. Regarding biochemical properties, it is known that procaine and dimethocaine can affect the binding site of DA (9). Indeed, the different affinities reported by Ritz et al. (9) for the DA-binding site of dimethocaine $\left(\mathrm{K}_{\mathrm{i}}=1.29 \mu \mathrm{M}\right)$, procaine $\left(\mathrm{K}_{\mathrm{i}}=104 \mu \mathrm{M}\right)$ and lidocaine $\left(\mathrm{K}_{\mathrm{i}}=3298 \mu \mathrm{M}\right)$ may explain the different results of the present study. It is noteworthy that lidocaine injection failed to impair the performance of mice in the elevated plus-maze task. Additional support for this hypothesis comes from the recent study of Graham and Balster (12) showing that local anesthetics belonging to the amide class, such as lidocaine, do not affect the dopaminergic system. Other mechanisms must definitely exist regarding procaine and dimethocaine modulation of memory processes.

The present data suggest that procaine and dimethocaine prolong the latency of retention in mice submitted to the plus-maze test, a memory impairing effect probably involving a non-anesthetic mechanism, and that this response is not gender related.

\section{Acknowledgments}

The authors thank Hoffmann-La Roche (Nutley, NJ USA) for supplying dimethocaine. 


\section{References}

1. Barret RJ, Leith NJ \& Ray OS (1974). An analysis of the facilitation of avoidance acquisition produced by $d$-amphetamine and scopolamine. Behavioral Biology, 11: 189-203.

2. Bracs PU, Gregory P \& Jackson DM (1984). Passive avoidance in rats: Disruption by dopamine applied to the nucleus accumbens. Psychopharmacology, 83: 70-75.

3. Fernandez-Tome MP, Sanchez-Blazquez P \& del Rio J (1979). Impairment by apomorphine of one-trial passive avoidance learning in mice: The opposing roles of the dopamine and noradrenaline systems. Psychopharmacology, 61: 43-47.

4. Kesner RP, Bierley RA \& Pebbles P (1981). Short-term memory: The role of amphetamine. Pharmacology, Biochemistry and Behavior, 15: 673-676.

5. Seliger DL (1975). Dose-response effects of $d$-amphetamine on passive avoidance learning in the rat. Psychopharmacology, 44: 191-193.

6. Packard MG \& White NM (1991). Dissociation of hippocampus and caudate nucleus memory systems by post-training intracerebral injection of dopamine agonist. Behavioral Neuroscience, 105: 295-306.

7. Johanson CE (1980). The reinforcing properties of procaine, chloroprocaine and proparacaine in rhesus monkey. Psychopharmacology, 67: 189-194.

8. Woolverton WL \& Balster RL (1982). Behavioral pharmacology of local anes- thetics: reinforcing and discriminative stimulus effects. Pharmacology, Biochemistry and Behavior, 16: 491-500.

9. Ritz MC, Lamb RJ, Goldberg SR \& Kuhar MJ (1987). Cocaine receptors on dopamine transporters are related to self-administration of cocaine. Science, 237: 1219-1223.

10. Silverman PB (1990). Cocaine and local anesthetics: stimulant activity in rats with nigral lesions. Psychopharmacology, 102: 185-190.

11. Rigon AR \& Takahashi RN (1996). Stimulant activities of dimethocaine in mice: reinforcing and anxiogenic effects. Psychopharmacology, 127: 323-327.

12. Graham JH \& Balster RL (1993). Cocainelike discriminative stimulus effects of procaine, dimethocaine and lidocaine in rats. Psychopharmacology, 110: 287-294.

13. Mansbach RS, Jortani SA \& Balster RL (1995). Discriminative stimulus effects of esteratic local anesthetics in squirrel monkeys. European Journal of Pharmacology, 274: 167-173.

14. Itoh $J$, Nabeshima $T$ \& Kameyama $T$ (1990). Utility of an elevated plus-maze for the evaluation of memory in mice: effects of nootropics, scopolamine and electroconvulsive shock. Psychopharmacology, 101: 27-33.

15. Sharma AC \& Kulkarni SK (1992). Evaluation of learning and memory mechanisms employing elevated plus-maze in rats and mice. Progress in Neuro-Psychopharmacology and Biological Psychiatry,
16: 117-125.

16. Ukai M, Miura M \& Kameyama T (1995). Effects of galanin on passive avoidance response, elevated plus-maze learning, and spontaneous alternation performance in mice. Brain Research Bulletin, 7: 12831286.

17. Miyazaki $\mathrm{S}$, Imaizumi $\mathrm{M}$ \& Machida $\mathrm{H}$ (1995). The effects of anxiolytics and anxiogenics on evaluation of learning and memory in an elevated plus-maze test in mice. Methods and Findings in Experimental and Clinical Pharmacology, 17: 121-127.

18. Laursen SE \& Belknap JK (1986). Intracerebroventricular injections in mice. Some methodological refinements. Journal of Pharmacological Methods, 16: 355-357.

19. Graeff FG, Viana MB \& Tomaz C (1993). The elevated T-maze, a new experimental model of anxiety and memory: effect of diazepam. Brazilian Journal of Medical and Biological Research, 26: 67-70.

20. Viana MB, Tomaz C \& Graeff FG (1994). The elevated T-maze: A new animal model of anxiety and memory. Pharmacology, Biochemistry and Behavior, 49: 549554.

21. Graeff FG, Viana MB \& Mora PO (1996). Opposed regulation by dorsal raphe nucleus 5-HT pathways of two types of fear in the elevated T-maze. Pharmacology, Biochemistry and Behavior, 53: 171177. 